\title{
Application of Xylanases from Amazon Forest Fungal Species in Bleaching of Eucalyptus Kraft Pulps
}

\author{
Roseli Garcia Medeiros ${ }^{1}$, Francides Gomes da Silva Jr. ${ }^{2}$, Sônia Nair Báo ${ }^{3}$, Rogério Hanada \\ and Edivaldo Ximenes Ferreira Filho ${ }^{1 *}$ \\ ${ }^{1}$ Laboratório de Enzimologia; Departamento de Biologia Celular; Universidade de Brasília; eximenes@unb.br; \\ 70910-900; Brasília - DF - Brasil. ${ }^{2}$ Laboratório de Química, Celulose e Energia; Departamento de Ciências \\ Florestais; ESALQ; Universidade de São Paulo; 13418-220; Piracicaba - SP - Brasil. ${ }^{3}$ Laboratório de Microscopia \\ Eletrônica;, Departamento de Biologia Celular; Universidade de Brasília; 70910-900; Brasília - DF - Brasil. \\ ${ }^{4}$ Laboratório de Patologia da Madeira; Instituto Nacional de Pesquisa da Amazônia; , Manaus - Amazônia - \\ Brasil.
}

\begin{abstract}
Crude xylanase preparations from Penicillium corylophilum, Aspergillus niger and Trichoderma longibrachiatum were used to treat Eucalyptus kraft pulp, prior to chlorine dioxide and alkaline bleaching sequences. The enzyme pretreatment improved brightness and delignification of non-delignified and oxygen-bleached samples of eucalyptus kraft pulp. Xylanase preparations from $\mathrm{T}$. longibrachiatum and $\mathrm{P}$. corylophilum were more effective to reduce pulp kappa number. A small reduction in viscosity was obtained when the oxygen-bleached pulp was treated with xylanase preparation from A. niger. For all enzyme samples, the best release of chromophoric material from the pulp was at $237 \mathrm{~nm}$. The enzyme preparation from $\mathrm{P}$. corylophilum was responsible for the highest release of reducing sugar at a dosage interval of 10-20 IU/g dry weight pulp. Scanning electron microscopy studies of oxygenbleached pulp after xylanase treatment revealed morphological changes, including holes, cracks, filament forming and peeling.
\end{abstract}

Key words: Xylan; xylanase; kraft pulp; pulp bleaching

\section{INTRODUCTION}

Xylan is the major hemicellulose component of the pulp fiber from hardwood (Viikari et al. 1990). Studies performed by Dahlman et al. (2003) showed that the surface of fiber pulps from softwood and hardwood have higher molecular masses xylan polymers and lower frequency of uronic acid side groups. Xylanases from a wide variety of fungal species have been reported to have potential application in the pulping and bleaching processes (Salles et al. 2000; Subramaniyan and Prema 2002; Viikari et al.
1990). The use of xylanases in prebleaching of cellulose pulp has become an alternative approach in eliminating chlorine in bleaching and reducing chlorinated organic compounds in bleach plant effluents, reduce the kappa number (residual lignin content in the pulp) and increase the brightness of the pulp (Filho 1998; Subramaniyan and Prema 2002; Techapun et al. 2003). They can be applied in elementary chlorine and chlorine dioxide containing bleaching sequences, as well as in combination with oxygen, ozone and hydrogen peroxide (Filho 1998; Techapun et al. 2003; Viikari et al. 1990; 1994). Xylanase removes the

Author for correspondence 
xylan portion in pulp selectively without affecting cellulose. The enzymatic hydrolysis of reprecipitated xylan on the surface of the fibers renders the fiber structure more permeable for lignin extraction (Filho 1998; Subramaniyan and Prema 2002). In a previous paper (Medeiros et al. 2003), ten fungal species from the Amazon forest were isolated, identified and evaluated for their capacity to produce xylan-degrading enzyme activity during growth in liquid medium containing oat spelt xylan as the carbon source. The best producing strains of $\beta$-xylanase activity were Penicillium corylophilum, Aspergillus niger and Trichoderma longibrachiatum. Xylanase activity from $A$. niger was the most thermostable of the three enzyme samples. The xylanase preparations were not active against filter paper and carboxymethyl cellulose as substrates. The aim of this work was to analysis the xylanase activity of crude extract obtained from cultures of Penicillium corylophilum, Aspergillus niger and Trichoderma longibrachiatum as alternative in kraft pulp bleaching.

\section{MATERIALS AND METHODS}

\section{Reagents}

Oat spelt xylan and carboxymethyl cellulose were purchased from Sigma Chemical Co. (St. Louis, $\mathrm{MO})$.

\section{Organism and enzyme production}

Trichoderma longibrachiatum, Penicillium corylophilum and Aspergillus niger were isolated from decomposed wood in the natural forest reserve of INPA (National Research Institute of Amazonia, Brazil) and purified as described before (Medeiros et al. 2003). They were maintained in BDA medium at $28^{\circ} \mathrm{C}$. For production of xylanase activity, the fungi were cultivated in Erlenmeyer flasks containing 1.0\% $(\mathrm{w} / \mathrm{v})$ oat spelt xylan in $300 \mathrm{ml}$ of minimal medium $\left(0.7 \% \quad \mathrm{KH}_{2} \mathrm{PO}_{4}, 0.2 \% \quad \mathrm{~K}_{2} \mathrm{HPO}_{4}, 0.05 \%\right.$ $\left.\mathrm{MgSO}_{4} 7 \mathrm{H}_{2} \mathrm{O}, \quad 0.1 \%\left(\mathrm{NH}_{4}\right)_{2} \mathrm{SO}_{4}\right)$ supplemented with $0.06 \%$ yeast extract. Flasks were inoculated with a suspension of $1.0 \times 10^{7} / \mathrm{ml}$ spores from routine subcultures. Cultures were grown at $\mathrm{pH}$ 7.0 for 5 days at $28^{\circ} \mathrm{C}$ with shaking at $100 \mathrm{rpm}$. Subsequently, the content of each flask was filtered through Whatman filter paper number 1. The supernatant solutions, hereafter called crude extracts, obtained from filtration procedure were stored at $4^{\mathrm{O}} \mathrm{C}$ for subsequent use as xylanase preparations.

\section{Enzyme assays}

Xylanase activity and reducing sugar were determined as reported before (Medeiros et al., 2003; Miller, 1959). Xylanase activity was expressed as $\mu \mathrm{mol}$ reducing sugar formed $\mathrm{min}^{-1}$ $\mathrm{ml}^{-1}$ enzyme solution, i.e., as IU $\mathrm{ml}^{-1}$.

\section{Pulp bleaching}

The kraft industrial cellulose pulp was obtained from a combination of Eucalyptus grandis, saligna and urophylla with a yield of 53\%. Nondelignified pulp had kappa number and viscosity of 18 and $43 \mathrm{cP}$, respectively. The pulp previously treated with oxygen had consistency, Kappa number and viscosity of $12 \%(\mathrm{w} / \mathrm{v}), 11$ and $21 \mathrm{cP}$, respectively. The kappa number (Tappi T236 cm$85)$ was expressed as the amount (ml) of a $0.1 \mathrm{~N}$ $\mathrm{KMnO}_{4}$ solution consumed by $1 \mathrm{~g}$ of moisture-free pulp. Brightness and viscosity tests were performed according to the recommendations of the Technical Association of the Pulp and Paper Industry (Atlanta, GA, USA), using protocols outlined in Tappi T452 om-92 and Tappi T230 om-94, respectively. Enzyme and water were added to pulp so that the final consistency reached $10 \%$ (10 g dry mass pulp/100 ml water). The enzyme charge was $5 \mathrm{IU} / \mathrm{g}$ moisture free pulp. Triplicates were incubated for $4 \mathrm{~h}$ at $50^{\circ} \mathrm{C}$ and $\mathrm{pH}$ 7.0. A typical ECF bleaching sequence adopted was: X-D1-E-D2, where ECF is elemental chlorine free, $\mathrm{X}$ is enzyme, D1 and D2 are first and second stage chlorine dioxide steps and $\mathrm{E}$ signifies alkaline extraction (Medeiros et al. 2002). Alkaline extraction step was not used in the brightness tests. A charge of $0.5 \%(\mathrm{v} / \mathrm{v})$ was applied for D1 and D2. In the control sequence the pulp underwent the same treatment with the omission of enzyme. A corresponding volume of distilled water was used instead of enzyme. After completing the bleaching sequence, the pulp was thoroughly washed three times with tap water, before further analysis. The experiments described above were carried out in triplicate. The standard deviation was less than $\pm 20 \%$ of the mean.

\section{Chromophore release}

The oxygen-bleached pulp was washed twice with distilled water in order to remove soluble reducing 
sugars and dried for $12 \mathrm{~h}$ at $70^{\circ} \mathrm{C}$. The pulp was weighed to determine the humidity. Enzyme preparations and $50 \mathrm{mM}$ phosphate buffer $(\mathrm{pH} 7.0)$ were mixed and added to the dried pulp to reach $10 \%$ consistency. The enzyme charges were 5,10 , 15, 20 and $25 \mathrm{IU} / \mathrm{g}$ moisture free pulp. Control was prepared using a denatured enzyme sample. The pulp was incubated at $50^{\circ} \mathrm{C}$ for $2 \mathrm{~h}$. Filtrates taken from the reaction mixture were diluted 1.5 -fold to monitor reducing sugars $(540 \mathrm{~nm})$ or 10 -fold to monitor chromophores release $(237 \mathrm{~nm}, 254 \mathrm{~nm}$, $280 \mathrm{~nm}, 465 \mathrm{~nm}$ ) using a Lambda-5 UV/VIS Spectrophotometer (Perkin-Elmer). The liberation of aromatic compounds was monitored by absorbance values at $237 \mathrm{~nm}$ and $254 \mathrm{~nm}$, while the absorbance at $280 \mathrm{~nm}$ indicated the presence of lignin. The remotion of hydrophobic compounds was detected by absorbance at $465 \mathrm{~nm}$. Absorbances measured were subtracted from control values Reducing sugar concentrations in pulp filtrates were determined by the dinitrosalicylic acid (DNS) method (Medeiros et al. 2002) and expressed as D-xylose equivalents. The experiments described above were carried out in triplicate. The standard deviation for all calculations were below 0.5 .

\section{Scanning Electron Micrograph}

The oxygen-bleached pulp showed alkaline $\mathrm{pH}$, inadequate for xylanase activity, requiring $\mathrm{pH}$ adjustment to neutral. For this purpose, was used chloridic acid. Enzyme and water were added to pulp so that the final consistency reached $10 \%$. The enzyme charge was $15 \mathrm{IU} / \mathrm{g}$ moisture free pulp. Control was prepared using a denatured enzyme sample. Triplicates were incubated for $4 \mathrm{~h}$ at $50^{\circ} \mathrm{C}$. Small samples of pulps were fixed in a freshly prepared solution of $2.5 \%$ glutaraldehyde in $0.05 \mathrm{M}$ phosphate buffer $\mathrm{pH}$ 7.0. Samples were dehydrated through a series of increasing acetone concentrations up to $100 \%(\mathrm{v} / \mathrm{v})$ and subjected to drying by the critical point method in liquid carbon dioxide and cemented to aluminium stubs and sputter-coated with gold. Specimens were examined by scanning electron microscopy (JEOL JSM 840A) operating at an accelerating voltage of $5.0 \mathrm{kV}$. The experiments described above were carried out in triplicate.

\section{RESULTS AND DISCUSSION}

The bleaching ability of crude xylanase preparations from $T$. longibrachiatum, $P$. corylophilum and A. niger was tested on nondelignified and oxygen-bleached kraft pulps. Release of chromophore is a better indicator of xylanase effect on the cellulose pulp than the liberation of reducing sugar, whereas the latter will continue being produced as result of xylanase attack on xylooligomers released by the initial hydrolysis of the xylan coating the fiber surface (Garg et al. 1998). Release of material absorbing at 237,254 and $280 \mathrm{~nm}$ by xylanase preparations increased with enzyme dosage, suggesting that it was released as a result of xylanase activity (Baraznenok et al. 1999). UV absorbance spectra of materials released from eucalyptus oxygenbleached kraft pulp gave the highest bleaching effect at $237 \mathrm{~nm}$ after $2 \mathrm{~h}$ of reaction time (Figs. 13 ). Compared with the $P$. corylophilum and $T$. longibrachiatum xylanase activities, xylanase from A. niger released more chromophores. According to Elegir et al. (1995), the liberation of material absorbing at $237 \mathrm{~nm}$ correlates with color release and enhances pulp brightness following bleaching. At enzyme dosages of $10-20 \mathrm{IU} / \mathrm{g}$ dry weight pulp, the amount of reducing sugars liberated by enzyme preparation from $P$. corylophilum was greater than that for xylanases from $T$. longibrachiatum and $A$. niger (Table 1). On the other hand, for an enzyme dosage of $25 \mathrm{IU} / \mathrm{g}$ dry weight pulp, the best performance was from xylanase preparation of $T$. longibrachiatum. The liberation of products absorbing at $465 \mathrm{~nm}$ by xylanases from $P$. corylophilum and $T$. longibrachiatum did not correlated with the release of chromophoric material (Figs. 1 and 2). However, the pulp treatment with xylanase from A. niger showed a small increased release in absorption at $465 \mathrm{~nm}$ (Fig. 3). The results obtained above suggested that the xylanases from $P$. corylophilum and $T$. longibrachiatum and not some other factor were responsible for the release of chromophoric material and there was a significant decrease in the aromaticity of residual lignin without a concomitant decrease in the color. The same result was described for xylanase preparations from Streptomyces thermoviolaceus (Garg et al. 1996).

The chemical properties of non-delignified and oxygen-bleached kraft pulps treated with $5 \mathrm{IU} / \mathrm{g}$ moisture free pulp of xylanase preparations from 
T. longibrachiatum, $P$. corylophilum and A. niger are summarized in Table 2. The kappa number of non-delignified pulp was reduced to $4.9,4.8$ and 4.3 with xylanase preparations from $P$. corylophilum, A. niger and T. longibrachiatum, respectively.

Table 1 - Release of reducing sugars from Eucalyptus kraft pulp by xylanases from A. niger, P. corylophilum and T. longibrachiatum.

\begin{tabular}{|c|c|c|c|c|c|c|}
\hline \multirow{3}{*}{ Xylanase source } & \multicolumn{6}{|c|}{ Reducing sugars (mg/ml) } \\
\hline & \multicolumn{6}{|c|}{ Dosage of enzyme (IU/g dry weight pulp) } \\
\hline & 5 & 10 & 15 & 20 & 25 & Control \\
\hline A. niger & 0.146 & 0.199 & 0.278 & 0.299 & 0.300 & 0.130 \\
\hline P. corylophilum & 0.161 & 0.279 & 0.332 & 0.369 & 0.343 & 0.134 \\
\hline T. longibrachiatum & 0.163 & 0.246 & 0.307 & 0.316 & 0.393 & 0.132 \\
\hline
\end{tabular}

Table 2 - Effect of xylanase enzyme treatment on Eucalyptus kraft pulp.

\begin{tabular}{lccc}
\hline Xylanase source & $\begin{array}{c}\text { Brightness } \\
(\boldsymbol{\%} \text { ISO })\end{array}$ & Viscosity $(\mathbf{c P})$ & Kappa number \\
\hline Control1 & 66.7 & 25.1 & 5.4 \\
Control2 & 83.3 & 21.5 & 1.5 \\
A. nigera & 70.8 & 31.6 & 4.8 \\
A. nigerb & 81.6 & 20.0 & 2.3 \\
P. corylophiluma & 73.0 & 33.4 & 4.9 \\
P. corylophilumb & 82.7 & 23.7 & 0.6 \\
T. longibrachiatuma & 71.6 & 33.0 & 4.3 \\
T. longibrachiatumb & 82.3 & 23.0 & 0.9 \\
\hline
\end{tabular}

${ }^{1}$ Non-delignified pulp without enzyme pretreatment.

${ }^{2}$ Oxygen-bleached pulp without enzyme pretreatment.

${ }^{a}$ Non-delignified pulp.

${ }^{\mathrm{b}}$ Oxygen-bleached pulp.

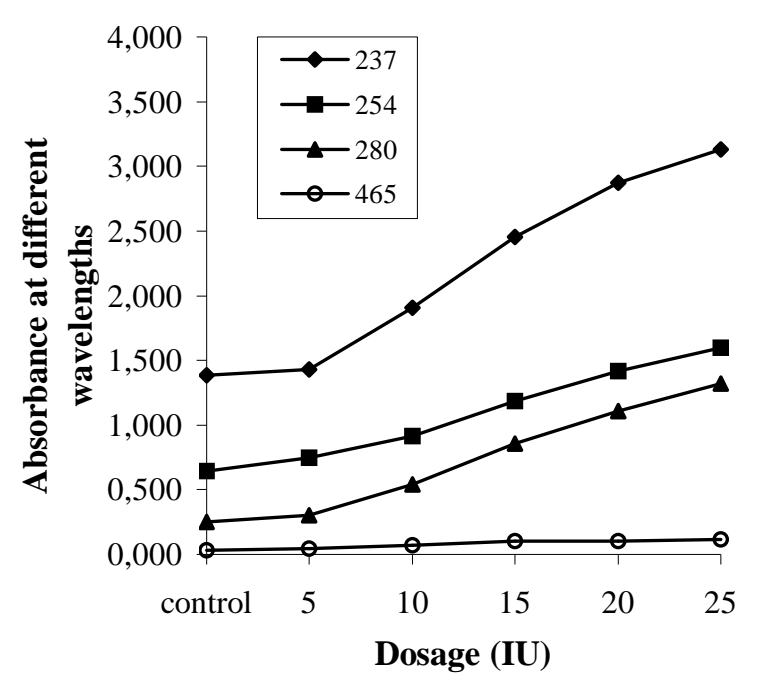

Figure 1 - Release of chromophoric material from oxygen-bleached eucalyptus kraft pulp by xylanase from $P$. corylophilum. 


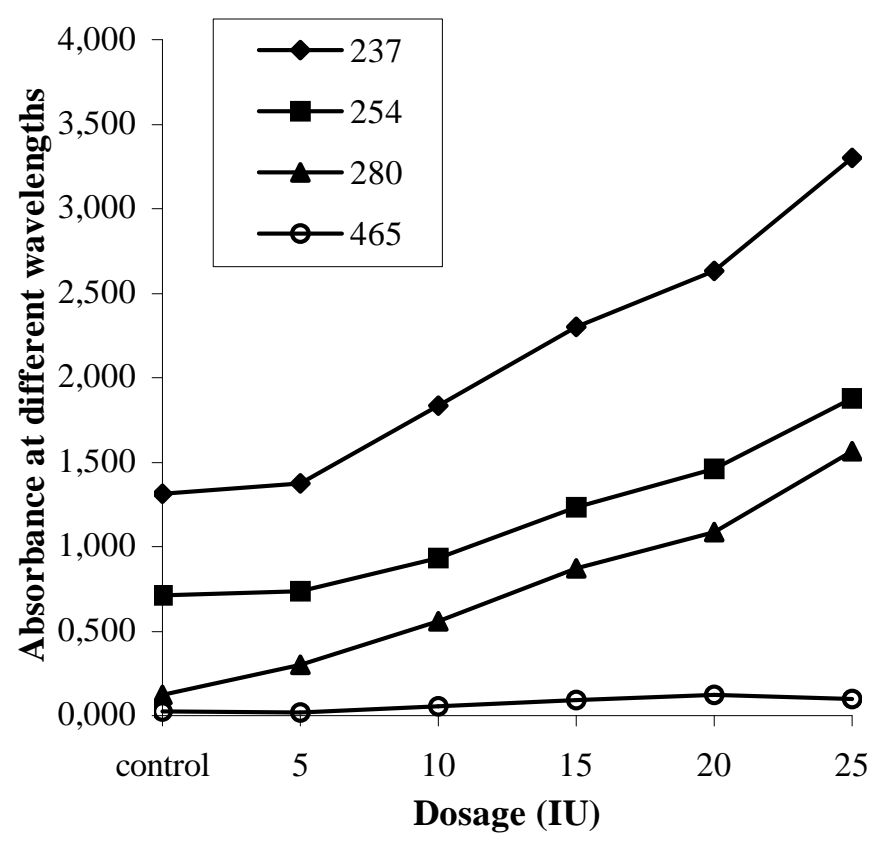

Figure 2 - Release of chromophoric material from oxygen-bleached eucalyptus kraft pulp by xylanase from $T$. longibrachiatum.

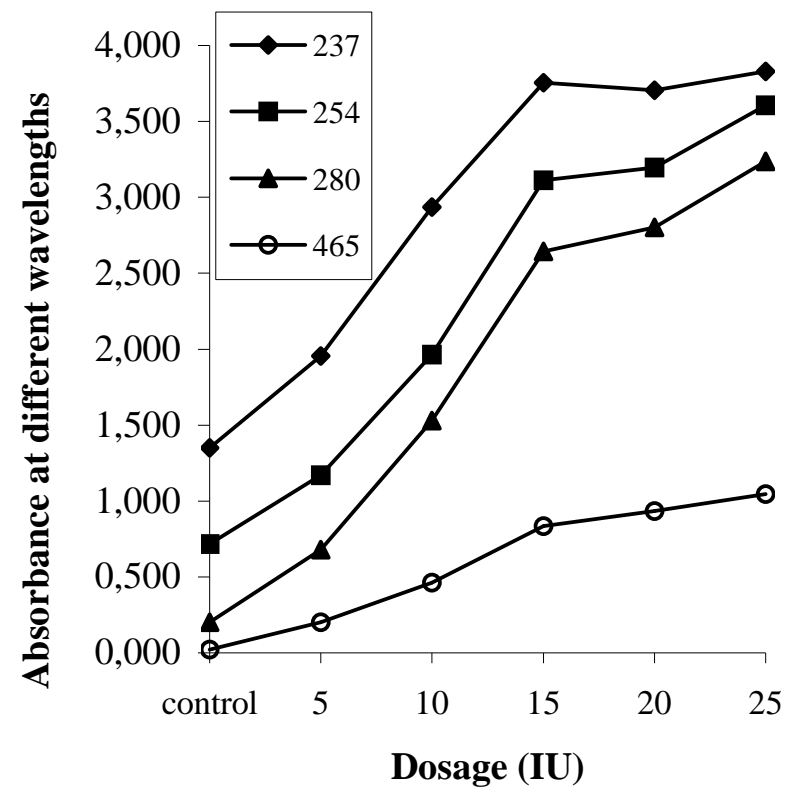

Figure 3 - Release of chromophoric material from oxygen-bleached eucalyptus kraft pulp by xylanase from A. niger. 
When xylanases from A. niger, T. longibrachiatum and $P$. corylophilum were used in the bleaching of oxygen-bleached kraft pulps, the kappa number decreased to $2.3,0.9$ and 0.6 after $2 \mathrm{~h}$ incubation, respectively. In comparison to control, treatment of both unbleached and oxygen-bleached pulps with xylanase from $P$. corylophilum viscosity increased to $33.06 \%$ and $10.23 \%$, respectively. According to Ragauskas et al. (1994), this improvement in the pulp viscosity could be caused by an accumulate of high molecular polysaccharides, which occurred when xylan was selectively removed. However, a small loss of viscosity was observed when oxygen-bleached pulp was treated with xylanase preparation from $A$. niger. This effect could be due to some other reason than cellulase activity (Medeiros et al.,
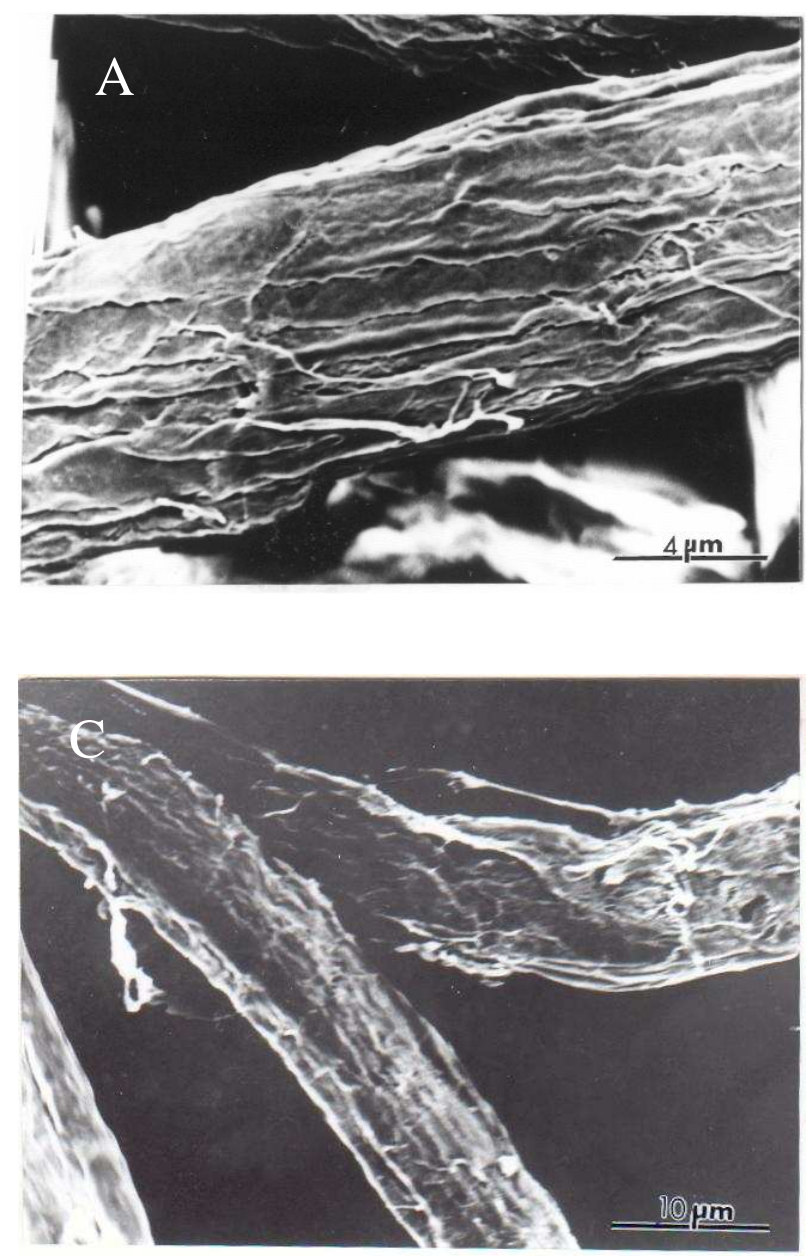

2002). Medeiros et al. (2003) reported that all xylanases preparations were not active against filter paper and carboxymethyl cellulose as substrates. For xylanase preparations from Acrophialophora nainiana, Humícola grisea var. thermoidea and Trichoderma harzianum, the viscosity of kraft pulp produced in the sequence $\mathrm{X}-\mathrm{D} 1-\mathrm{E}-\mathrm{D} 2 \mathrm{was}$ higher than the control sequence (Medeiros et al., 2002).

All tested xylanase preparations were effective in increasing the brightness of the pulps. In this case, the enzyme preparation from $P$. corylophilum was more efficient with an increase of $82.7 \%$ in the degree of brightness on oxygen-bleached pulps.

The results of scanning electron microscopy studies of control and xylanase-treated pulps are presented in Fig. 4.
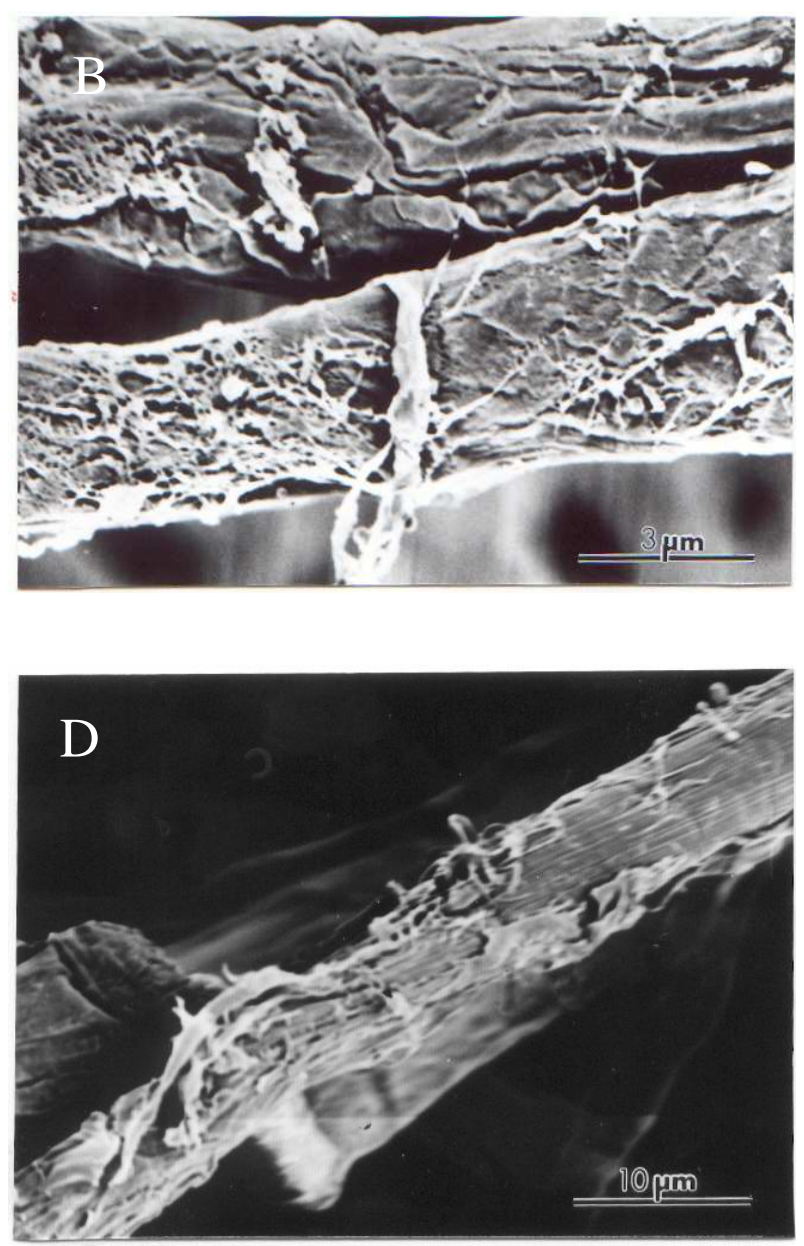

Figure 4 - Scanning electron micrograph of eucalyptus oxygen-bleached kraft pulp: control (A); treated with xylanase from A. niger (B); treated with xylanase from P. corylophilum (C) and treated with xylanase from T. longibrachiatum (D). 
Xylanases were responsible for noticeable changes in the surface architecture of the oxygen-bleached pulp compared to the surface of untreated pulp. Some reports in the literature have focused on scanning electron microscopy of xylanase treated pulps and shown that enzymatic prebleaching opens up the pulp structure (Salles et al. 2005). Morphological changes, including holes, cracks, filaments and peeling of the fiber surfaces were evident after the pulp treatment with xylanase preparations of A. niger, $P$. corylophilum and $T$. longibrachiatum. The same result was described for cellulase-free xylanases from Acrophialophora nainiana and Humicola grisea var. thermoidea (Salles et al., 2005). Garg et al. (1998) reported that the treatment of celullose fibers with xylanase from $S$. thermoviolaceus showed extensive separation of microfibrils. Scanning electron microscopy of eucalyptus pulp after treatment with Streptomyces sp. QG11-3 xylanase resulted in better porosity, swelling up and separation of pulp microfibrils and pulp fibers (Beg et al. 2000). In other reports, the use of an enzyme preparation, containing cellulase and xylanase activities from $H$. insolens on Douglas-fir kraft pulps did not present cleavages or pit enlargments of the fiber surfaces and changes to internal morphology of the fibers (Mansfield et al. 1997). However, it did show changes in the outermost fiber surface of the pulp.

In conclusion, results showed that crude xylanase preparations from $T$. longibrachiatum, $P$. corylophilum and A. niger were effective for improving some properties of cellulose kraft pulps. The results of the scanning electron microscopy studies revealed that a defibrillation of the microfibrils was detected for the pulp enzymatically treated when compared with the control. Further experiments should be focused on the use of different enzyme mixtures and their effects on treatment of kraft pulps.

\section{ACKNOWLEDGEMENTS}

This work was supported by research grant from Bioamazônia/BASA (Brazil). EX.F.F.

and R. G. M. were recipient of research fellowship and posgraduate maintenance scholarship, respectively from CNPq (Brazil).

\section{RESUMO}

Amostras de xilanases de extratos brutos de Penicillium corylophilum, Aspergillus niger $e$ Trichoderma longibrachiatum foram utilizadas no branqueamento de polpa kraft de eucalipto antes das sequiências alcalina e dióxido de cloro. $\mathrm{O}$ pré-tratamento enzimático melhorou a alvura e o processo de deslignificação de amostras de polpa kraft de eucalipto não-tratada e tratada com oxigênio. Amostras de xilanases de $T$. longibrachiatum e $P$. corylophilum foram mais efetivas na redução do número kappa da polpa. A polpa tratada com oxigênio sofreu uma pequena redução na sua viscosidade quando incubada com amostra de xilanase de A. niger. Para todas as amostras de xilanases, a maior liberação de cromóforos da polpa foi a $237 \mathrm{~nm}$. A amostra de xilanase de $P$. corylophilum liberou maior quantidade de açúcar redutor da polpa, utilizando dosagem de 10-20 UI/g de peso seco da polpa. Estudos de microscopia eletrônica de varredura revelaram várias alterações morfológicas da polpa tratada com oxigênio tais como a formação de buracos, rachaduras e filamentos.

\section{REFERENCES}

Baraznenok V. A., Becker E. G., Ankudimova N. V. and Okunev N. N. (1995), Characterization of neutral xylanases from Chaetomium cellulolyticum and their biobleaching effect on eucalyptus pulp. Enzyme Microb. Technol., 25, 651-659.

Beg Q. K., Bhushan B., Kapoor M. and Hoondal G. S. (2000), Enhanced production of a thermostable xylanase from Streptomyces sp. QG-11-3 and its application in biobleaching of eucalyptus kraft pulp. Enzyme Microb. Technol., 27, 459-466.

Dahlman O., Jacobs A. and Sjöberg J. (2003), Molecular properties of hemicelluloses located in the surface and inner layers of hardwood and softwood pulps. Cellulose, 10, 325-334.

Elegir G., Sykes M. and Jeffries T. (1995), Differential and synergistic action of Streptomyces endoxylanases in prebleaching of kraft pulps. Enzyme Microb. Technol., 17, 954-959. 
Filho E. X. F. (1998), Hemicellulase and biotechnology. In: Pandalai, S. G. (ed.), Recent Research Development in Microbiolology, Trivandrum, Índia: Research Signpost. pp. 165176.

Garg A. P., McCarthy A. J. and Roberts J. C. (1996), Biobleaching effect of Streptomyces thermoviolaceus xylanase preparations on birchwood kraft pulp. Enzyme Microb. Technol., 18, 261-267.

Garg A. P., Roberts J. C. and McCarthy A. J. (1998), Bleach boosting effect of cellulase-free xylanase of Streptomyces thermoviolaceus and its comparison with two commercial enzyme preparations on birchwood kraft pulp. Enzyme Microb. Technol., 18, 594-598.

Mansfield S. D., Jong E., Stephens R. S. and Saddler J. N. (1997), Physical characterization of enzymatically modified kraft pulp fibers. $J$. Biotechnol., 57, 205-216.

Medeiros R. G., Silva Jr F. G., Salles B. C., Estelles R. S. and Filho E. X. F. (2002), The performance of fungal xylan-degrading enzyme preparations in elemental chlorine-free bleaching for eucalyptus pulp. J. Ind. Microbiol. Biotechnol., 28, 20 - 206.

Medeiros R. G., Hanada R. and Filho E. X. F. (2003), Production of xylan-degrading enzymes from Amazon Forest fungal species. Int. Biodet. Biod., 52, 97-100.

Miller G. L. (1959), Use of dinitrosalicylic acid reagent for the determination of reducing sugar. Anal. Chem., 31, 426-428.

Ragauskas A., Poll K. M. and Cesternino A. J. (1994), Effects of xylanase pretreatment procedures on nonchlorine bleaching. Enz. Microb. Technol., 16, 492-495.
Salles B. C., Cunha R. B., Fontes W., Sousa, M. V. and Filho, E. X. F. (2000), Purification and characterization of a new xylanase from Acrophialophora nainiana. J. Biotechnol., 81, 199204.

Salles B. C., Medeiros R. G., Báo S. N., Silva Jr. F. G. and Filho E. X. F. (2005), Effect of cellulasefree xylanases from Acrophialophora nainiana and Humicola grisea var. thermoidea on eucalyptus kraft pulp. Process Biochem., 40, 343-349.

Subramaniyan S. and Prema P. (2002), Biotechnology of microbial xylanases: enzymology, molecular biology, and application. Crit. Rev. Biotechnol., 22, 33-64.

Techapun C., Poosaran N.,Watanabe M. and Sasaki K. (2003), Thermostable and alkaline-tolerant microbial cellulase-free xylanases produced from agricultural wastes and the properties required for use in pulp bleaching bioprocess: a review, Process Biochem., 38, 1327-1340.

Viikari L., Kantelinen A., Poutanen K. and Ranua, M. (1990), Characterization of pulps treated with hemicellulolytic enzymes prior to bleaching. In: Kirk T. K. and Chang H.-M. (eds), Biotechnology in Pulp and Paper Manufacture. Applications and Fundamental Investigations. Boston: ButterworthHeinemann. pp. 145-151.

Viikari L., Kantelinen A., Sundquist J. and Linko M. (1994), Xylanases in bleaching: from and idea to the industry. FEMS Microbiol. Rev., 13, 335 - 355.

Received: December 12, 2004; Revised: December 07, 2005; Accepted: October 18, 2006. 